\title{
Use of Different Tillage Tools for Minimizing Number of Passes in Secondary Tillage Operations
}

\author{
Manjeet Prem $^{1 *}$, Prem Ranjan ${ }^{2}$, K.L. Dabhi ${ }^{1}$, A.V. Baria ${ }^{1}$ and Pema T. Lepcha ${ }^{2}$ \\ ${ }^{1}$ Department of Farm Machinery and Power Engineering, College of Agricultural Engineering \\ and Technology, Anand Agricultural University, Godhra, Gujarat-388110, India \\ ${ }^{2}$ Department of Agricultural Engineering, NERIST, Nirjuli, Arunachal Pradesh-791109, India \\ *Corresponding author
}

\section{A B S T R A C T}

Soil tillage is one of the most important operations in the crop production system and consumes a large amount of energy and time than any other operation. The cost, energy and time requirement during the tillage operation mainly depends on the soil condition,

\section{Keywords}

Combination tillage, Instability index, Moldboard ploughing, Secondary tillage operations, Tillage tools.

Article Info

Accepted:

23 October 2017

Available Online:

10 December 2017 power source and the tool used during the operation. The cost and the timeliness of operation assume critical importance while deciding the type of tillage tools. In this paper, an attempt has been made to overview the effect of the different tillage tools on reducing the number of passes in the secondary tillage operations. The combined tillage tool with the combination of a disk harrow and a Cambridge roller has been developed in Iran. Three treatments were namely disk harrow once; disk harrow twice and combined machine were applied after moldboard ploughing. Findings showed that increasing rotational speed from 130 to $165 \mathrm{rpm}$, decreased the mean weight diameter and instability index. A methodology for the prediction of draft requirements under the combination of tillage implements in the different soil and operating conditions have also been developed. Combination tillage implement comprising cultivator and a single-acting disk harrow in sequence $(\mathrm{C}-\mathrm{DH})$ with a total cutting width of $2.1 \mathrm{~m}$ had draft found to be within 7.4 to $11.1 \mathrm{kN}$ with an associated slip of 10.5 to $22.4 \%$. The overall performance index was found to be higher for combination tillage implement as compared to that of individual tillage implements indicating the better efficiency of the tractor-implement combinations. It can be concluded that new combined machine would be a substitute for several disking and allows the operation to complete in one pass.

\section{Introduction}

Tillage consumes a large part of the energy in mechanized agriculture. Tillage or soil preparation has been an integral part of traditional agricultural crop production practice (Gill and Vandenberg, 1968; Kumar and Chopra, 2016). Tillage breaks the soil, enhances the release of soil nutrients for crop growth, destroys weeds and enhances the circulation of water and air within the soil
(Reicosky and Allmaras, 2003; Kumar and Chopra, 2013). Combined tillage is the act of using two or more different types of tillage implements or tools at the same time to manipulate control or reduce the number of operations in the field (Al-janobi and Alsuhaibani, 1998). Manian and Kathirvel (2001) reported that combined machines are more complex than passive tilling implements 
or rotary machines, but these machines can unite the advantages of active and passive machines and they can create lower resistance than the passive machines and, at the same time, they can ensure lower specific work than the active, rotary machines. Javadi and Hajiahmad (2006) reported that draft and clod mean weight diameter (MWD) significantly decreased when combined tillage operation is done compared to single operation with many passes.

Above reviews show the importance of combined tillage operation in a single pass to save time, money, fuel in land preparation. Sahu and Raheman (2006) stated that operations simultaneously utilizing two or more different types of tillage tools or implements to simplify, control or reduce the number of operations over a field are called combined tillage. The combination that enables the task to be completed in the shortest time with minimum operating cost and energy requirement is usually selected (Onwualu and Watts, 1998). Combined machines are complex than passive tilling implements or rotary machines, but these machines can unite the advantages of the active and passive machine and they can create lower resistance than the passive machines and at the same time they can ensure lower specific work (Kepner et al., 1972)

Most of the primary tillage operation is for unsettling the compression of soil and root growth. In this regard, Ruci and Vilde (2006) reported that ploughing is one of the most power-consuming and expensive processes in agricultural production. Craciun et al., (2004) reported some advantages about combined machines for seedbed preparation and sowing in terms of the draft. Therefore, the present investigation was conducted for the use of different tillage tools for minimizing number of passes in secondary tillage operations

\section{Materials and Methods}

A conventional offset disk harrow with 140 $\mathrm{cm}$ working width and $53 \mathrm{~cm}$ disk diameter was used. A Cambridge roller was selected, which was more efficient for clod breaking. An extended chassis was added on disc chassis to attach roller behind the disk. Divisions of roller were attached to each other enabling to cover disk harrow width. The attachment was done in such a way to put the pulling centre of disk and roller in direction with pulling a line of the tractor. The combined machine was then evaluated in the field and its effect on the soil physical and mechanical properties was determined. Completely Randomized Block Design with three replications was adopted as follows after ploughing for the three selected treatments viz., 1) Disk harrow once 2) Disk harrow twice 3) Combined machine (disk harrow + Cambridge roller). Bulk density on a dry basis was determined before and after the operation.

The depth ranging from $0-10$ and $10-20 \mathrm{~cm}$ were selected as working depth for all the treatments. For this test un-disturbed samples were taken from the plots by core sampler and dried for $24 \mathrm{~h}$ at $105^{\circ} \mathrm{C}$ in an oven. Clod mean mass diameter was determined using different sieve sizes before and after operations in three replications. Penetration resistance was measured by 10 insertions in each plot before and after operations. A penetrometer (SP 1000) was used with $12.83 \mathrm{~mm}$ cone diameter and 30-degree angle based on ASAE standard. Soil moisture content was also determined during cone index recording. Soil surface profile measurement was developed to compare surface uniformity left after each treatment. The device consisted series of Aluminum rods that could be placed on plough furrow. The loose rods were tightened by bolts after placement. By transferring and measuring the movement of each rod and 
calculating standard deviation, the uniformity was determined (Javadi and Hajiahmad, 2006).

\section{Tillage equipment}

A combo plough has four essential parts which include a chassis, a disk plough, a set of rotary blades and a transmission system. The combo plough is attached to a tractor three-point linkage system and driven by the tractor power take-off shaft (PTO). Power is transferred from the PTO to the gearbox. The drive direction is changed by $90^{\circ}$ at the horizontal shaft to the rotary blade shaft. A clutch safety system is placed between the universal joint and the gearbox to prevent overload. The disk implement consists of a standard disk having $61 \mathrm{~cm}$ diameter. The position of the rotary blade was determined according to the upward soil movement at the end of the disk (Ahmad and Amran, 2004). The rotary shaft has three kinds of blades: straight (S), C-shaped and L-type. The soil penetration resistance in each experimental plot was determined using a penetrograph (80 $\mathrm{mm}$ long and $10 \mathrm{~mm}$ cone diameter) at a depth of 0 to $80 \mathrm{~mm}$.

\section{Test procedure}

The test was performed based on $2 \times 3$ factorial treatment in following the same pattern: Completely randomized block design (CRBD) with three replications. Block dimensions were $25 \times 27 \mathrm{~m}^{2}$. Clod mean weight diameter was determined using different sieve sizes $(8,4.75,2.8,2,0.5$, and $0.3 \mathrm{~mm}$ ) in three replications after the operation. The main plots were allocated to rotary speeds (130,147 and $165 \mathrm{rpm})$ and subplots were allocated to the three types of blades namely, straight blade (S), C-shaped and L-shaped. Aggregate stability or stability index (SI) was measured using a wet-sieving apparatus to determine the mean weight diameter, wet basis (MMDw) and dry sieving to determine the mean mass diameter, dry basis (MMDd). The method of wet-sieving was adapted from Kemper and Rosenau (1986). The wet-sieving apparatus duration was $10 \mathrm{~min}$ and 50 oscillations per minute and SI was calculated using the following formula:

Instability Index (II) = MMDd - MMDw Stability index $(\mathrm{SI})=1 \div$ instability index (II)

Experiments were conducted to determine the influence of various types of blades and rotational speeds on selected soil physical properties. The soil physical characteristics investigated were MMDd, MMDw, to find out the SI, SII and percentage of aggregate size distribution for aggregates between 2 and $8 \mathrm{~mm}\left(\mathrm{ASDd}_{8}\right)$. Clod mean mass diameter $\left(\mathrm{MMDd}_{100}\right)$ was determined using different sieve sizes $(100,50,14,6.3 \mathrm{~mm})$ in three replications after the operation.

The tillage depth for disk plough was $20 \mathrm{~cm}$. The tractor PTO speed of $540 \mathrm{rpm}$ was reduced to $216.5 \mathrm{rpm}$ using a gearbox. The rotary blade speeds of 130,147 and $165 \mathrm{rpm}$ were obtained by changing the adjustable gear sprockets $(13: 23,14: 22$ and 15:21) in the transmission system. The travel speed used for all treatments was $7.2 \mathrm{~km} / \mathrm{h}$.

\section{Measurements of soil characteristics}

Twenty-seven soil samples were collected from the field during the tillage experiments from each plot at depths of 0 to 15 and 15 to $30 \mathrm{~cm}$. Soil samples were classified by mechanical analysis using the pipette method.

\section{Draft and depth of operation}

The draft requirement of tillage implements and its depth of operation in the field were measured with an instrument attached to the 
three-point linkage of a tractor. For measuring draft values, implements were pulled at a different speed and depth for a strip of $25 \mathrm{~m}$ length and simultaneously data on pulling force and the angle made by the links were recorded through multi-channel data acquisition system.

\section{Slip}

The measurement of wheel slip was based on the fixed number of a rear wheel revolution. The distance covered in ten wheel revolutions was recorded with and without load and the values were used to calculate slip using the following expression.

$\mathrm{S}=\left(\mathrm{d}_{\mathrm{t}}-\mathrm{d}_{\mathrm{a}}\right) / \mathrm{d}_{\mathrm{t}} \times 100$

Where $\mathrm{S}$ is slip (\%), $\mathrm{d}_{\mathrm{t}}$ is distance covered in 10 revolutions of drive wheel at no load in the field $(\mathrm{m})$ and $\mathrm{d}_{\mathrm{a}}$ is distance covered in 10 revolutions of drive wheel with a load in the field (m).

\section{The volume of soil handled}

The volume of soil handled per unit time could be expressed as:

$\mathrm{Vs}=\mathrm{AFC} \times \mathrm{Td} \times 10000$

Where Vs is the volume of soil tilled per unit time $\left(\mathrm{m}^{3} / \mathrm{h}\right)$, AFC is actual field capacity $(\mathrm{ha} / \mathrm{h})$ and $\mathrm{Td}$ is the depth of operation (m).

\section{Mean mass diameter of soil aggregate}

The mean mass diameter (MMD) of the soil aggregate was computed as:

$\mathrm{MMD}=\sum \mathrm{WsMs} / \sum \mathrm{Ws}$

Where Ws is the weight of soil sample retained over $S^{\text {th }}$ sieve $(\mathrm{g})$ and $\mathrm{Ms}$ is the class of mean size for $S^{\text {th }}$ sieve $(\mathrm{mm})$.

\section{Fuel energy input to the tractor}

The fuel (diesel) energy input $(\mathrm{Fe})$ to the tractor to carry out a tillage operation could be expressed as $\mathrm{Fe}=\mathrm{FC} \times \mathrm{CV}$

Where Fe is fuel energy input (MJ/ha), FC is fuel consumption ( $1 / \mathrm{ha}$ ) and $\mathrm{CV}$ is the calorific value of diesel (MJ/l).

\section{Overall performance}

The overall performance of the tractor implement combination was expressed in terms of tillage performance index (TPI), which is considered to be directly proportional to $\mathrm{Vs}$ and $\mathrm{Si}$ and inversely proportional to MWD and fuel energy $(\mathrm{Fe})$.

Mathematically, it could be expressed as:

TPI $\alpha \times[\mathrm{Vs} /(\mathrm{MWD} \times \mathrm{Fe})]$

$\mathrm{TPI}=\mathrm{K} \times[\mathrm{Vs} /(\mathrm{MWD} \times \mathrm{Fe})]$

Where $\mathrm{K}$ is proportionality constant. While comparing the tillage performance of different tillage implements in same soil condition $\mathrm{K}$ could be absorbed in the equation

\section{Results and Discussion}

The effect of treatments on the bulk density at 0-10 cm depth was non-significant. However, it was noted that combined machine had minimum bulk density. The results showed that bulk density decreased after the operation. This was mainly due to clod breaking and loosening of soil surface layer. There was no difference in bulk density at 10$20 \mathrm{~cm}$ depth for all the treatments. The reason was due to working depth of implements, which was mostly in the range of $0-10 \mathrm{~cm}$. In cases of similar effect, it is clear that combined machine would be preferable as operation could be done in one pass. Time is also a dominant factor for tillage operation 
and the combined machine could save time significantly. Using the disk harrow one time had almost no effect on clod breaking as no change was recognized in mean weight diameter before and after the operation. The combined machine showed the greatest difference followed by twice disking treatment. One-time disking does not significantly affect or break the clods and more disking is often needed. However statistical analysis showed that there was the non-significant difference between treatments after operation with $95 \%$ confidence. It can be confirmed that combination of disk harrow with other equipment, which enabled to break the clods and create uniform surface would avoid several disking. Combination of disk harrow and spiked harrows was successfully used in the past. The results showed that combined machine had the maximum effect to decrease penetration resistance, particularly at $10-20 \mathrm{~cm}$ depth. There was no significant difference between once and twice disking treatments. Penetration resistance increased in $20 \mathrm{~cm}$ depth range, which was due to plough pan in the field. It was reported that field ploughed continuously for more than three years and existing of plough pan was expected. Results revealed that combined equipment created maximum uniformity (minimum non-uniformity) followed by disking twice and once. This result was fairly close to areal condition in the field, where combined machine left more even surface than others.

\section{Tractive performance parameters}

\section{Draft}

The results obtained are the average of the three replications. The measured draft forces for a cultivator, offset disk harrow and C-DH for 100 and $150 \mathrm{~mm}$ depths of operation. From this figure, it can be seen that the draft values for a cultivator, offset disk harrow and
C-DH implements are found to be within 6.8 to $10.3 \mathrm{kN}, 4.7$ to $7.4 \mathrm{kN}$ and 7.4 to $11.1 \mathrm{kN}$, respectively for the test range of soil conditions, depths and speeds of operation. The draft values of all tillage implement tested show a polynomial increase with an increase in depth and speed. The draft of C$\mathrm{DH}$ was found to be the highest among the tillage implements tested. This could be due to a higher volume of soil handled per unit width as compared to other tillage implements and also its design and manner of soil handling. The draft values of combination tillage implement as compared to its individual tillage implements were higher by 1.1 to $9.3 \%$.

\section{Slip}

It can be noticed that the slip of driving wheels of the tractor with cultivator, offset disk harrow and C-DH implements were found to vary from 8.6 to $16.9 \%, 7.5$ to $13.9 \%$ and 10.5 to $22.4 \%$, respectively. Further for all implements, it increased with increase in both depth and speed. This behaviour could be due to the higher draft requirement of an implement with an increase in depth, speed and soil strength causing thrust requirement at drive wheels to increase and thus resulting in more slip.

\section{Mean mass diameter of soil aggregates}

The MMD of soil aggregates was determined using the data obtained from the sieve analysis of soil sample collected after a single pass of each tillage implement. It was found that the MMD of soil aggregates varied from 17.0 to $25.7 \mathrm{~mm}$ for the tillage implements used. The disk harrow produced the lowest MMD of soil aggregates $(17.0 \mathrm{~mm})$, while the cultivator produced the highest MMD (18.8 $\mathrm{mm}$ ). This could be due to both cutting and pulverize actions by disk harrow as compared to only cutting action by cultivator. It can also 
be seen that the MMD of soil aggregates produced by $\mathrm{C}-\mathrm{DH}$ combination tillage implement was lower than the conventional cultivator.

\section{Actual field capacity}

The actual field capacity of various tillage implements tested in the field varied from 0.51 to $0.63 \mathrm{ha} / \mathrm{h}$. A maximum of $0.63 \mathrm{ha} / \mathrm{h}$ and a minimum of $0.51 \mathrm{ha} / \mathrm{h}$ were observed for cultivator and disk harrow, respectively. This could be due to the difference in speed at which they were tested. The actual field capacity of cultivator was found to be $6.35 \%$ higher than that of combination tillage implement. This was due to more time required during turning for combination tillage implement as well as the lesser speed of operation due to higher slip.

\section{The volume of soil handled per unit time}

The volume of soil handled per unit time during tillage operation was found to be varying from 637.5 to $945.0 \mathrm{~m}^{3} / \mathrm{h}$. As compared to the cultivator, the volume of soil handled per unit time for C-DH implement was $6.35 \%$ lesser due to higher slip incurred and losses in time during turning.

\section{Field efficiency}

The field efficiency of different tillage implements tested varied from 74.2 to $80.2 \%$. The highest and lowest field efficiencies were found for disk harrow and C-DH combination tillage implement, respectively. This could be due to more time loss during turning of the $\mathrm{C}$ DH implement as compared to disk harrow.

\section{Fuel consumption}

The fuel consumption of $31 \mathrm{~kW}$ tractors for all the tillage implements tested varied from 3.6 to $4.3 \mathrm{l} / \mathrm{h}$. It was found that $\mathrm{C}-\mathrm{DH}$ tillage implement consumed the highest amount of fuel $(4.3 \mathrm{l} / \mathrm{h})$, while the lowest $(3.6 \mathrm{l} / \mathrm{h})$ was observed for disc harrow. This could be due to more volume of soil handled by $\mathrm{C}-\mathrm{DH}$ as compared to other tillage implements. However, on the basis of the area covered, the fuel consumption was found to be lowest (6.2 $1 / h$ ) for cultivator due to its higher actual field capacity.

\section{Tillage performance index}

The overall performance of different tillage implements tested during the study was expressed in terms of tillage performance index (TPI). It can be seen that the TPI varied from 0.22 to 0.26 for the tillage implements tested. The highest TPI was found for C-DH tillage implement, while the lowest was found for the cultivator. This could be due to more volume of soil handled and higher pulverization by $\mathrm{C}-\mathrm{DH}$ as compared to disk harrow and cultivator.

It can be concluded that there were some benefits of using new machine in the secondary tillage operation. Soil uniformity was significantly improved by using the combined machine. In case of similar effect, it can be also recommended that combined machine would be preferable reducing the number of passes, time and costs. The results obtained indicated that no significant differences were noted between types of blades. The blade rotational speeds had highly significant effects on selected parameters $\left(\mathrm{MMD}_{\mathrm{d}}, \mathrm{MMDwASD} \mathrm{d}_{\mathrm{d}}\right.$ and $\left.\mathrm{MMD}_{\mathrm{d} 100}\right)$. The effects of blade type were similar. The concept of reference tillage tool and reference soil condition could be used successfully to predict the drafts of various combination tillage implements and draft utilization ratio for a rear passive set of the combination tillage implement in field conditions with scale factors related to soil properties and implement geometry. The developed 
combination tillage implement could be operated with $31 \mathrm{~kW}, 2 \mathrm{WD}$ tractor in sandy clay loam soil at an average moisture content of $10 \%$, normal depth and speed within the slip range of $15 \%$. The TPI of combination tillage implements was found to be higher than the TPI of respective individual tillage implements. Thus, the new combined machine would be a substitute for several disking and allows the operation to complete in one pass.

\section{References}

Ahmad D, Amran FA. Energy prediction model for disk plough combined with a rotary blade in wet clay soil. Int. J. Eng. Technol. 1(2):102-114, (2004).

Alam, A. Farm mechanization: Rising energy intensity. The Hindu Survey of Indian Agriculture, 181-191, 2000.

Al-Janobi, A..A, Al-Suhaibani, S.A., Draft of primary tillage implements in sandy loam soil. ApplEng Agric 14(4), 343 348, 1998.

Bernacki, H., Haman, J., Kanafojski, Cz. Agricultural Machines, Theory and Construction, vol. I. Scientific Publications Foreign Co-operation Centre of the CISTEI, Warsaw, Poland, 1972.

Bukhari, S.B, Laszlo, L., Pal, S., Devrajani, B.T., Performance of tillage tool combinations. Agric. Mechan. Asia, Africa, Latin America 12 (4), 33-36, 1981.

Chamen, W.C., Cope, R.F., Patterson, D.F., Development and performance of high output rotary digger. J. Agric. Eng. Res. 24 (4), 301-318, 1979.

Craciun V, Nitescu E, Balan O, Magureanu M (2004). Combined machines for seedbed preparation and sowing a necessity for applying advanced technologies in crop production. Balkan Agric. Eng. Rev. Vol. 6.
Ghazavi, M.A., Design and development of a plow for Iranian condition. Proceeding of the First Conference on Agricultural Machinery and Mechanization, Karaj, Iran, 1998.

Gill, W.R. and Vandenberg, G. E. Soil Dynamics in Tillage and Traction. Agriculture Handbook No. 316. USDAAgricultural Research Service, Washington. D.C., 1968.

Javadi A, Hajiahmad A (2006). Effect of a new combined implement for reducing secondary tillage operation. Int. $\mathbf{J}$. Agric. Biol. 8(6):724-727.

Javadi, A. and M. Shahidzadeh, investigating possibility to break plow pan during plowing. Agric. Eng. Res. J., 24: 45-59, 2005

Kailappan, R., Manian, R., Amuthan, G., Vijayaraghavan, N.C., Duraisamy, G. Combination tillage tool. I. (Design and development of a combination tillage tool) Agric. Mechan. Asia, Africa, Latin America 32(3), 19-22, 2001

Kemper WD, Rosenau RC Aggregate stability and size distribution In. A. Klute (ed) Methods of soil analysis. Part 1. 2nd ed. Pp. 425-442, ASA and SSSA, Madison, WI, (1986).

Kepner, R.A., Bainer, R. and Barger, E.L. Principle of Farm Machinery, (3rd Edn). CBS Publisher, New Delhi, India, 1972.

Kumar, V. and Chopra, A.K. (2013).Reduction of weeds and improvement of soil quality and yield of wheat by tillage in Northern Great Plains of GangaRiver in India. International Journal of Agricultural Science Research, 2(8): 249-257.

Kumar, V. and Chopra, A.K. (2016). Influence of summer tillage on soil characteristics, weeds diversity and crop yield of certain vegetable crops grown in Tarai region of Ganga River, India. International Journal of Agricultural 
Science Research, 5(3): 040-050.

Manian, R., and Kathirvel, K. Development and evaluation of an active - passive tillage machine. AMA, Agricultural Mechanization in Asia, Africa and Latin America (Farm Machinery Industrial Research Corporation) 32 (1): 9-18, 2001.

Manian, R., Nagaiyan, V., Kathirvel, K. Development and evaluation of combination tillage bed furrow-former. Agric. Mechan. Asia, Africa, Latin America 30 (4), 22-29, 1999.

Nicholson, R.I., Bashford, L.L., Parkhurst, A.M. Energy requirements for tillage from a reference tool. ASAE Paper No. 84-1028. St. Joseph, Mich.: ASAE, 1984.

Oni, K. C. and J. S. Adeoti. Tillage effects on differently compacted soil and on cotton yield in Nigeria. Soil and Tillage Research 8: 89-100, 1986.

Onwualu, A.P. and Watts, K.C. Draft and vertical forces obtained from dynamics soil cutting by plane tillage tools. Soil and Tillage Research, 48, 239-253, 1998.

Raheman, H., and Roul, A. K. Combination Tillage Implement for High Horse Power 2WD Tractors. Agricultural Mechanization in Asia, Africa, and Latin America 44 (3): 75-79, 2013.
Ruci S, Vilde A (2006). Impact of the share inclination angle on the plough body draft resistance. Zemdirbyste / Agriculture 93(4):166179. Reicosky, D. C. and Allmaras, R. R. Advances in tillage research in North American cropping systems. J. Crop Prod. 8:75$125,2003$.

Sahu, R. K. and Raheman, H. Draught Prediction of Agricultural Implements using Reference Tillage Tools in Sandy Clay Loam Soil. Biosystems Engineering 94 (2), 275-284, (2006)

Sahu, Rohit K., and Hifjur. Raheman. An approach for draft prediction of combination tillage implements in sandy clay loam soil. Soil \& Tillage Research (Elsevier B.V.) 90: 145-155, 2005.

Vilde A (1999). Energetic and economic estimation of soil tillage systems. In Wydawnic two Akademii Rolniczej Szczecin (eds.) Folia Universitas Agriculturae Stetinensis 195, Agricultura 74. Poland, pp. 213-222.

Yusuf, D.D., Asota, C.N. Design, development and performance evaluation of an once-over tillage machinery utilizing a single-axle tractor. Agric. Mechan. Asia, Africa, Latin America 29, 1998.

\section{How to cite this article:}

Manjeet Prem, Prem Ranjan, K.L. Dabhi, A.V. Baria and Pema T. Lepcha. 2017. Use of Different Tillage Tools for Minimizing Number of Passes in Secondary Tillage Operations. Int.J.Curr.Microbiol.App.Sci. 6(12): 3109-3116. doi: https://doi.org/10.20546/ijcmas.2017.612.363 